Article

\title{
Variable Arrangements Between Residential and Productive Activities: Conceiving Mixed-Use for Urban Development in Brussels
}

\author{
Michael Ryckewaert ${ }^{1, *}$, Jan Zaman ${ }^{2}$ and Sarah De Boeck ${ }^{1,3}$ \\ ${ }^{1}$ Cosmopolis Centre for Urban Research, Vrije Universiteit Brussel, Belgium; E-Mail: michael.ryckewaert@vub.be \\ ${ }^{2}$ Flemish Planning Bureau for the Environment and Spatial Development, Department of Environment and Spatial \\ Development, Flemish Government, Belgium; E-Mail: jan.zaman@vlaanderen.be \\ 3 perspective.brussels, Belgium; E-Mail: sarahdeboeck@hotmail.com \\ * Corresponding author
}

Submitted: 17 March 2021 | Accepted: 16 June 2021 | Published: 23 September 2021

\begin{abstract}
Mixing productive economic activities with housing is a hot topic in academic and policy discourses on the redevelopment of large cities today. Mixed-use is proposed to reduce adverse effects of modernist planning such as single-use zoning, traffic congestion, and loss of quality in public space. Moreover, productive city discourses plead for the re-integration of industry and manufacturing in the urban tissue. Often, historical examples of successful mixed-use in urban areas serve as a guiding image, with vertical symbiosis appearing as the holy grail of the live-work mix-discourse. This article examines three recent live-work mix projects developed by a public real estate agency in Brussels. We investigate how different spatial layouts shape the links between productive, residential, and other land uses and how potential conflicts between residents and economic actors are mediated. We develop a theoretical framework based on earlier conceptualisations of mixed-use development to analyse the spatial and functional relationships within the projects. We situate them within the housing and productive city policies in Brussels. From this analysis, we conclude that mixed-use should be understood by considering spatial and functional relationships at various scales and by studying the actual spatial layout of shared spaces, logistics and nuisance mitigation. Mixed-use is highly contextual, depending on the characteristics of the area as well as policy goals. The vertical symbiosis between different land uses is but one example of valid mixed-use strategies along with good neighbourship, overlap, and tolerance. As such, future commercial and industrial areas will occur in various degrees of mixity in our cities.
\end{abstract}

\section{Keywords}

Brussels; housing; mixed-use; productive activities; urban development

\section{Issue}

This article is part of the issue "Future Commercial and Industrial Areas" edited by Angela Million (TU Berlin, Germany) and Felix Bentlin (TU Berlin, Germany).

(C) 2021 by the authors; licensee Cogitatio (Lisbon, Portugal). This article is licensed under a Creative Commons Attribution 4.0 International License (CC BY).

\section{Introduction}

In this article, we investigate three mixed-use projects that are currently under construction in Brussels. We selected projects that combine residential uses with productive uses categorised in Brussels' land use plan as "(light) industrial and material production" (see Table 3; Government of the Brussels Capital Region, 2001). We provide an ex-ante assessment of the func- tional and design characteristics of these projects against the backdrop of the specific planning context of the Brussels Capital Region and its recent urban development goals.

To do that, we first address the state-of-the-art concerning single-use zoning and the various pleas for mixed-use development, in particular addressing the combination of residential and productive uses, as a specific variety of mixed-use development that is currently 
gaining interest against the backdrop of productive city discourses (Cities of Making, 2018, 2020; Ferm \& Jones, 2016, 2017).

Secondly, we give a brief characterisation of the (historical) space of live-work mix in Brussels and how this urban fabric was transformed in the wake of modernist urban planning and functional zoning strategies. We then introduce the key urban development goals that explain current spatial policy with regards to housing and productive activities against the backdrop of the specific institutional and governance context of the Brussels Capital Region.

Thirdly, we establish an analytical framework to evaluate the spatial and functional organisation of live-work mix as they occur in the projects under study. This is based on a critical reading of existing planning concepts and conceptualisations for mixed-use planning.

Lastly, we apply the analytical categories to the three selected mixed-use projects and situate them against the specific urban development context and goals in the Brussels Capital Region. This allows us to identify several conditions and design characteristics that warrant successful mixed-use projects in metropolitan contexts confronted with conflicting land-use needs for (affordable) housing and productive activities. This provides nuance to the discourse on what successful mixed-use entails and how it could be assessed.

\section{Overview of Single-Use Zoning and Motivations for Mixed-Use in Light of Productive City Discourses}

The place of economic activities in the city has been at the centre of the conceptualisation of spatial planning since the modernist era. One of the tenets of modernist urban planning was the regulation of conflicting urban activities, resulting in the principle of zoning. It is seen as an instrument to regulate urban "congestion" (Fischler, 1998), with the aim of increasing safety, efficiency, and health (Choay, 1965; Grant, 2002; Mumford, 2000; van Eesteren \& van Rossem, 1997; van Es et al., 2014).

The differentiation of uses in different districts of the city emerged in Germany during the late 19th century. The zones defined under these regulations were not single-use but rather comprised various degrees of mixed-use, as continues to be standard practice in Germany under federal legislation (Hirt, 2007; Logan, 1976). In the Frankfurt Ordinance of 1891, some (noxious) industries were banned from the two zones aimed to attract single-family housing, while the factory zone only discouraged residences (Logan, 1976). The remaining three zones all provided a mix of residential, commercial, and industrial uses (Logan, 1976). Single-use zones emerged in the early 20th century in the US, where "especially residential ones are suitable for a singly type of human activity" (Hirt, 2007, p. 437). The 1916 New York City Zoning Ordinance introduced a "hierarchy of uses at whose apex is the single-family detached house" (Perrin, 1977, as cited in Fischler, 1998, p. 178). In the same year, "Berkeley, California gave zoning... the exclusive single-family residential district" and "put industrial districts off-limits for residential development" (Fischler, 1998, p. 174). Hirt (2007, p. 441) draws attention to a further distinction in zoning practices between the US and Europe:

The US system presumes that the entire city must be pre-emptively divided into relatively large, homogenous areas, each under a specific land use classification. Under the German approach each city block may end up in a different land use category, and this is conducive to a much more fine-grained diversity of uses.

The latter is mainly the case in urban areas, much less so in fringe areas where single-use is also dominant in the German case. Indeed, while early European zoning practices provided for mix, the publication of the results of the fourth International Congress of Modern Architecture (CIAM-Congrès Internationaux d'Architecture Moderne) on the "Functional City" of 1933 (van Es et al., 2014) by Le Corbusier in 1943 as "the Athens Charter" (Gold, 1998) played a great role in making expansive, single-use zoning the dominant landuse planning approach in the post-war years, in Europe and beyond. The Athens Charter proposed the strict separation of dwelling, leisure, work, and transport areas as very vast and detached single-use areas buffered by green spaces (Gold, 1998).

As far as industries are concerned, the development of the industrial park in Great Britain since the 1930s provided a model to organise industrial growth. While early industrial parks such as the Team Valley Trading Estate in Manchester occupied a water-based location, the success of the model became widespread as industrial areas popped up along the emerging highway networks in the US and Europe. In the wake of modernist zoning and the advent of a welfare state economy in the years after World War II, the space of production was largely isolated and removed from the city fabric in (generic) business and industrial parks (Castells \& Hall, 1994; Ryckewaert, 2011).

As the crisis of zoning-based urban planning became apparent in a loss of urbanity in single-use urban areas, pleas to reintroduce a mix of urban activities in urban design became more important. These pleas focus on a reconnection between residential, recreational, and commercial uses, the reduction of car use and transit-oriented development, and improvements in public space to develop vibrant, lively, liveable, and sustainable urban areas (Gehl, 2011; Jacobs, 1993; National Academies of Sciences, Engineering, and Medicine, 2004). According to Grant, "'mixed use' has become a mantra in contemporary planning, its benefits taken for granted" (2002, p. 71). In many cases, historical examples of mixed urban fabrics and building typologies serve as the leitmotiv of such urbanistic endeavours, as is the case of the new urbanism movement 
(Grant, 2002; Hebbert, 2003). Cited benefits of mixeduse are the reduction of commuting times, a livelier urban atmosphere, social mix, and more varied temporality of uses throughout the day (Grant, 2002; Hirt, 2007; Jacobs, 1993).

Spatial planning has, however, struggled to regulate mixed-use land-use plans with zoning regulations that rely on fixed numerical proportions between types of activities. Such purely quantitative regulations fail to create planning frameworks that allow co-existence and the mediation of nuisances. In response to this, researchers have sought different conceptualisations of mix that rather focus on different degrees and intensities of mix as a tool to assess the complementarity of activities and the possibilities to cluster them together in space (Hoppenbrouwer \& Louw, 2005; Leinfelder \& Pisman, 2008). Very often, such conceptualisations occur in a context where the efficient use of scarce land resources pushes for urban densification.

Examples of successful mixed-use projects combining residential uses with commercial, recreational, or services abound. In Home Work City (van Gameren et al., 2019), many fine-grained examples of mix are listed and primarily include workshop spaces, hybrids between office and maker spaces, in addition to small scale commercial spaces and home offices. Good examples of a successful mix between residential, industrial, and manufacturing activities are rarer. Moreover, historical patterns of how this live-work mix was realised in the past often serve as a point of reference. These historical conditions included a pressing need for the proximity of productive uses to rapid and high volume means of traffic (waterways and railroads), as well as closeness to consumer and labour markets. This led to vertical production schemes (Rappaport, 2020) as well as a small-scale vertical mix of housing over workspace or shops (Vandyck et al., 2020), and closely-knit horizontal juxtaposition of workers' housing near the factory. The density associated with the vertical factory reoccurs in present-day projects and architectural competitions, where vertical mix at the building or plot level often emerges as a guiding image for mixed-use projects (Borret et al., 2018; IABR-Atelier Brussels Productive Metropolis, 2016; Lane \& Rappaport, 2020). From a designer's point of view, the more complex combinations of live-work mix garner great interest in the recent literature (van Gameren et al., 2019).

In recent years, the reintroduction of the spaces of production in cities is on the agenda of both urban scholars and policymakers alike (Cities of Making, 2020; Ferm \& Jones, 2016, 2017). In metropolitan urban areas, rising land prices and pressures on the residential market result in "industrial gentrification." Lucrative residential uses tend to push out remaining productive activities from neighbourhoods (Curran, 2007; Yoon \& Currid-Halkett, 2015). Various urban governments - such as New York, where the rezoning of industrial land in Brooklyn was curbed and former industrial premises such as the
Brooklyn Navy Yard have been preserved as spaces for work, hosting a variety of productive activities-have attempted to combat these tendencies. Cities such as London and Vienna are pursuing productive city policies in recent planning documents (London City Hall, 2021; Rosenberger, 2017).

\section{The Brussels Spatial, Policy, and Planning Context for Live-Work Mix Projects}

Until the mid-20th century, Brussels remained the main industrial heart of Belgium. Industries were mostly concentrated around the canal connecting the city to the seaport of Antwerp in the north, and the industrial coal and steel basin around Charleroi in the south. Other productive hotspots emerged around the numerous Brussels' train stations or in the marshy lands of the tributary valleys of the Senne river (De Boeck et al., 2020). These areas consisted of a tight mix of workshops, small factories and warehouses, and residences, organised primarily in closed building blocks. Productive activities occupied the insides of the building blocks, with housing fronting the street, or organised on the upper floors (Vandyck et al., 2020).

From the 1950s onward, government policy focused on the transformation of Brussels into an administrative capital and host to international company headquarters (De Beule et al., 2017; Ryckewaert, 2011). This went hand in hand with modernist planning principles, resulting in the delocalisation of industries in peripheral industrial parks, the construction of an (urban) highway network, and the demolition of popular neighbourhoods to build office districts. These developments led to fierce anti-modernist sentiments among citizen activist groups and spatial planners from the 1970s onward, impacting how land-use planning was implemented in the Regional Land-Use Plan in 2001 (Government of the Brussels Capital Region, 2001). The 1962 planning law had introduced legally binding land-use plans in Belgium. Due to the process of federalisation, in 1989, the Brussels Capital Region obtained competency on spatial planning policy, alongside the two other federal regions of Belgium, Flanders and Wallonia. In 2001, Brussels adopted a land-use plan that determined land use at the level of the building block. In addition to single-use "industrial" or "harbour" zones, it discerned between "residential" and "typical" housing blocks, as well as "mixed" and "strongly mixed" building blocks (perspective.brussels, 2018). In short, the Brussels land-use plan explicitly recognised the mixed-use nature of the urban tissue, fixing varying proportions between residential, office, and productive uses at the building block level.

Two interrelated socio-spatial issues dominate urban development policy in Brussels with regards to residential and productive land uses. A first issue is the continuing urban flight that followed the "destructive" planning policies of the 1950s. Quantitatively, this negative demographic trend was curbed in the early 2000s. 
Demographic projections predicted important population growth, leading to an adaptation of the Regional Land-Use Plan via the Demographic Land-Use Plan in 2013 (perspective.brussels, 2018). Qualitatively, the continuing suburbanisation of families in the higher income groups (De Maesschalck et al., 2015) supported a policy that aimed for the production of subsidised middleincome owner-occupied housing (Dessouroux et al., 2016). Foreign migration fills in the gaps left by these suburbanites, maintaining population growth even if this is weaker than anticipated in the Demographic Land-Use Plan. While Brussels enjoys a fair share of higher-income foreign immigrants as well as youngsters settling in Brussels from other parts of the country after graduation, foreign immigration (documented as well as undocumented) is also marked by groups that occupy a much less favourable socioeconomic position.

This sheds light on a second socio-spatial reality, the existence of a large "crescent" of low-income neighbourhoods in the canal area and around the Brussels city centre. These strongly mixed areas are marked by high proportions of persons without a secondary education degree, high unemployment rates, a young population, and high shares of residents with a migration background. This second socio-spatial reality explains another qualitative housing challenge, the high shortage of affordable low-income rental housing (Dessouroux et al., 2016). In addition, it explains the interest in productive city strategies in Brussels, as providing space for productive activities is seen as a means to maintain short-term skilled jobs within the capital region (Cities of Making, 2018; Orban et al., 2021). Due to industrial gentrification, productive space within the Brussels Capital Region is in continuous decline (De Boeck \& Ryckewaert, 2020).

As housing policy and spatial planning are a competency of the regions, the Brussels Capital Region deploys urban development policies that try to tackle these socio-spatial challenges within its own borders even if the functional metropolitan area stretches out far into the bordering regions. The important and conflicting needs for middle- and low-income housing, as well as productive activities, result in fierce competition for these scarce land resources. In 1974, the Brussels Capital Region established a public real estate development agency to support its urban development plans. This agency, citydev.brussels, is the main provider of business space and middle-income housing, and increasingly partners with public and semi-public agencies producing low-income housing. They have a dedicated branch focusing on mixed projects.

A first example of how these policies and challenges impact mixed-use projects can be found in the rezoning of industrial areas into enterprise areas in urban environment under the regulations of the Demographic Land-Use Plan of 2013 (perspective.brussels, 2018). In these areas, the regular conception of mixed-use areas as residential ones where other uses (industrial, office) are "tolerated" is reversed. Early assessments of developments in these areas reveal several problems. First of all, opening them to residential uses engages real estate dynamics that prioritise high-value offices and retail over material production (De Boeck \& Ryckewaert, 2020), resulting in industrial gentrification (Yoon \& Currid-Halkett, 2015). Second, the involvement of private developers leads to residential development aimed at higher income groups and subsidised housing for middle-income groups. Truly affordable social housing is only included in some of the more recent projects. Third, the planning regulations in most of the projects push for vertical mix projects at the building or plot level. This increases potential conflicts between housing and productive uses (De Boeck \& Ryckewaert, 2020). Moreover, this necessitates joint management of the workshop spaces and housing, while it is not clear which actor would be responsible to take up this role (Uyttebrouck et al., 2021).

\section{Analytical Framework to Study Spatial and Functional Relationships Between Land Uses in Mixed-Use Projects}

Hoppenbrouwer and Louw (2005) developed a conceptual framework based on four dimensions, four scales, and three urban texture components to discuss mixed urban developments (Figure 1, Table 1). Starting from Rowley's (1996) definition, they consider the "shared premises" dimension, where two or more activities share the same "point" or premise. This can only happen in one specific area of a building, e.g., a room being used for working and living. Vertical mixed-use, a multi-story building with different activities on different floors, and sequential mixed-use (time dimension) are also considered on a building scale. The horizontal dimension is only discussed from the "block" scale. The urban texture component in the Hoppenbrouwer and Louw scheme (henceforth $\mathrm{H}-\mathrm{L}$ scheme) of mixed-use contains grain, density, and interweaving, and also mentions the notion of permeability referring to the layout of roads, streets, and paths, and how this offers choices for pedestrians.

Leinfelder and Pisman (2008) propose a different approach, based on the characteristics of functional and spatial relations between activities in research to determine the mixed land-use characteristics of various regions in Flanders (Figure 2). The scheme is also tested in case studies at the "micro-level... of a real project" (Leinfelder \& Pisman, 2008, p. 2). In the Leinfelder and Pisman scheme (henceforth L-P scheme), the spatial relationships oscillate between "spreading" and "concentration." This resonates with density in the urban texture component of the $\mathrm{H}-\mathrm{L}$ scheme. The L-P scheme further qualifies the functional relationships among uses, distinguishing between "separating" and "connecting." It considers land uses that are separate but that maintain functional interactions as having a "network" relationship, and simply "separate" if they have no interactions. 

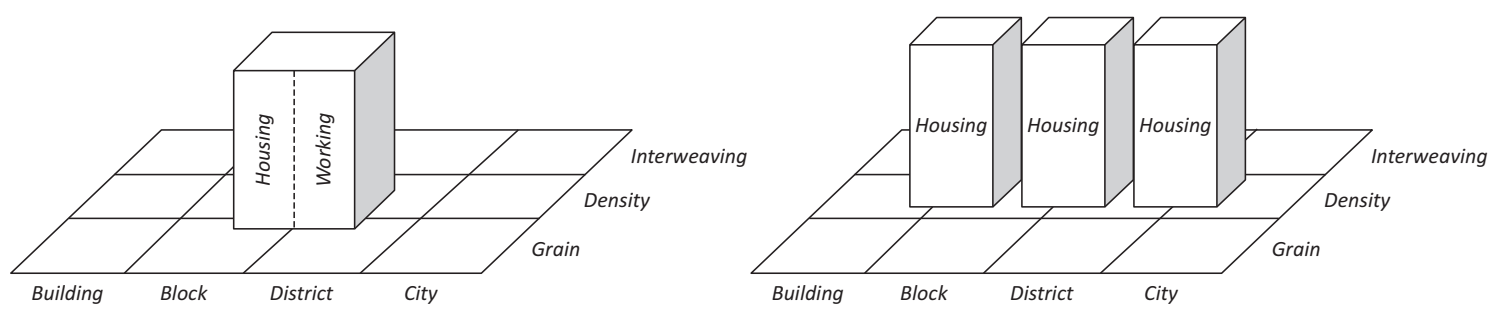

III. Vertical dimension

IV. Time dimension


Figure 1. Multidimensional typology of mixed-use by Hoppenbrouwer and Louw (2005, p. 973): A conceptual model of mixed land use for four dimensions.

Adjoining land uses with functional interactions are considered "good neighbours," but if they simply co-exist without mutual nuisances, they are in a "tolerance" relationship. Finally, land uses that share space without functional interactions are in a relationship of "overlap," while in the presence of such interactions, they entertain a "symbiotic" relationship. Combined with the time dimension that indicates if the interactions are temporal or permanent, this leads to 12 possible models of mixed land use.

The L-P scheme does not include "scale," but they mention the concept as a characteristic of multiple land use and also refer to the density that occurs in the "urban texture" component of the $\mathrm{H}-\mathrm{L}$ scheme. As the L-P scheme is mainly applied at the regional level, there is no distinction between the horizontal or vertical organisation of land uses. Depending on the scale and spatial organisation, some of the 12 models embedded in the scheme are not illustrations of mixed-use, but rather revert to single-use zoning (Leinfelder \& Pisman, 2008). At the level of a district, city, or region, the "tolerance" and "good neighbours" types of adjacent multiple uses can conform to a mixed-use reality, depending on the grain of the respective uses. On the level of a building or a block, adjacent activities organised in the horizontal or vertical dimension of the "tolerance" or "good neighbours" type will always conform to a mixed-use reality. Therefore, it seems useful to combine the "dimensions," "urban texture," and "scale" of the H-L scheme with the L-P scheme as this provides a more complete analytical framework to evaluate the existence and quality of mixed-use on a building block or district scale.

In Table 2, we combine the various dimensions of the $\mathrm{H}-\mathrm{L}$ and $\mathrm{L}-\mathrm{P}$ schemes. The table illustrates the various concepts and how they relate to each other. Given its multidimensional nature, we consider the table to list relevant categories that allow assessing mixed-use in projects and spaces at various scales. Not every dimension is relevant for all (combinations of) scales, spatial dimensions, relationships, or urban texture characteristics, as indicated in Table 2 by the grey areas. In addition, the scheme should not be read as normative, discerning between "good" and "bad" types of mixed-use. The types should rather be seen as varying degrees of mixed-use, ranging from single-use ("separation"), low-intensity mix of uses to multiple-use, and

Table 1. Multidimensional typology of mixed-use by Hoppenbrouwer and Louw (2005, p. 974): Components of mixed land use; dimensions versus scale and urban texture.

\begin{tabular}{|c|c|c|c|c|c|c|c|}
\hline \multirow[b]{2}{*}{ Dimensions } & \multicolumn{4}{|c|}{ Scale } & \multicolumn{3}{|c|}{ Urban Texture } \\
\hline & Building & Block & District & City & Grain & Density & Interweaving \\
\hline Shared premises dimension & $x$ & & & & & $x$ & \\
\hline Horizontal dimension & & $x$ & $x$ & $x$ & $x$ & $x$ & $x$ \\
\hline Vertical dimension & $x$ & $x$ & & & $x$ & $x$ & $x$ \\
\hline Time dimension & $x$ & $x$ & & & $\mathrm{x}$ & $x$ & \\
\hline
\end{tabular}


TIME

Temporary/Permanent

SPACE

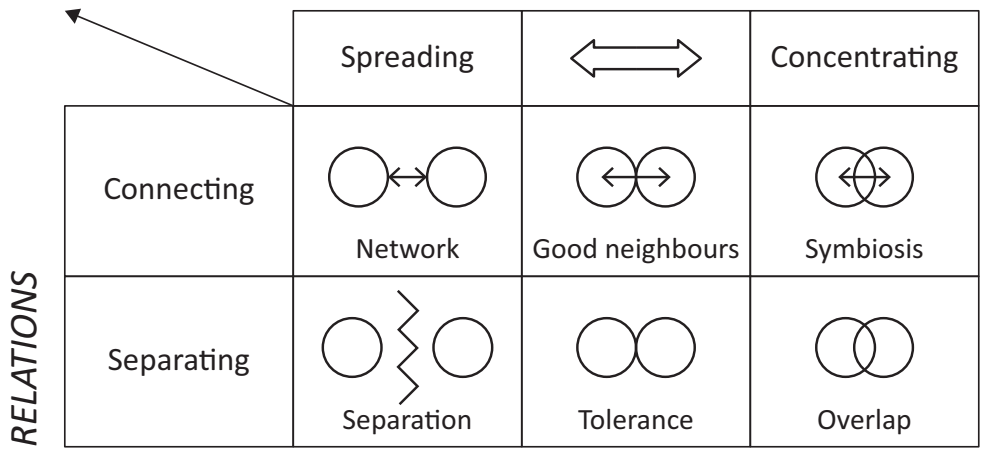

Figure 2. Typology of mixed-use as proposed by Leinfelder and Pisman (2008, p. 4).

high-intensity mix of uses ("symbiosis;" Leinfelder \& Pisman, 2008). Nonetheless, it seems that the more intense modes of mix-use regularly reoccur in productive city discourses and projects, as indicated before. In particular, vertical symbiosis seems to serve as a guiding image in design competitions.

For the Brussels Metropolitan Region, horizontal mixed-use is the city's reality, as it would be in most cities. Even on a district level, there are only a limited number of districts that do not have some form of horizontal mixed-use. For our research, we will introduce an extra scale, the "project." The examples we study consist of multiple buildings, in some cases spread out over (parts of) multiple blocks or introducing new public streets in existing blocks. We consider the "project" scale as flexible, bridging the fixed spatial scales of building, block, district, and city. Indeed, when an entire city part is planned as a composition of mixed-use neighbourhoods, the "project" level extends between the "district" and "city" scale, as is the case in the Amsterdam Eastern Docklands (Hoppenbrouwer \& Louw, 2005). The Werksviertel in Munich (Werksviertel, n.d.) is an example of a neighbourhood planned as a combination of mixed-use blocks, where the "project level" is situated between the "block" and "district" scale.

\section{Three Cases of Live-Work Mix in Brussels}

From the recent and rapid development of new mixeduse projects in Brussels, we selected three projects that have a similar position in the Brussels Capital Region (Figure 3) and are promoted by citydev.brussels. All selected cases are developed by the "mixed projects" division of citydev.brussels. They all combine residential with "(light) industrial and material productive" uses (Government of the Brussels Capital Region, 2001). According to citydev's definition, spaces for (light) industrial activities are characterised by a rectangular floor space of over $200 \mathrm{~m}^{2}$, a limited number of columns and internal walls, a floor to ceiling height of more than $5 \mathrm{~m}$, and a large entrance gate that allows vans to enter the workspace. These light industrial spaces are used by manufacturing companies, construction companies, and storage, wholesale, and urban logistics. They all rely on larger heavy goods vehicles for supplies and delivery; they have an environmental impact (smell, noise) that is present but acceptable for nearby housing and residential areas. In addition to the residential and (light) industrial and material productive uses, various other uses (see Table 3) occur in the projects, in varying degrees. The projects involve public as well as private actors. They

Table 2. Analytical scheme of mixed-use, based on Hoppenbrouwer and Louw (2005) and Leinfelder and Pisman (2008).

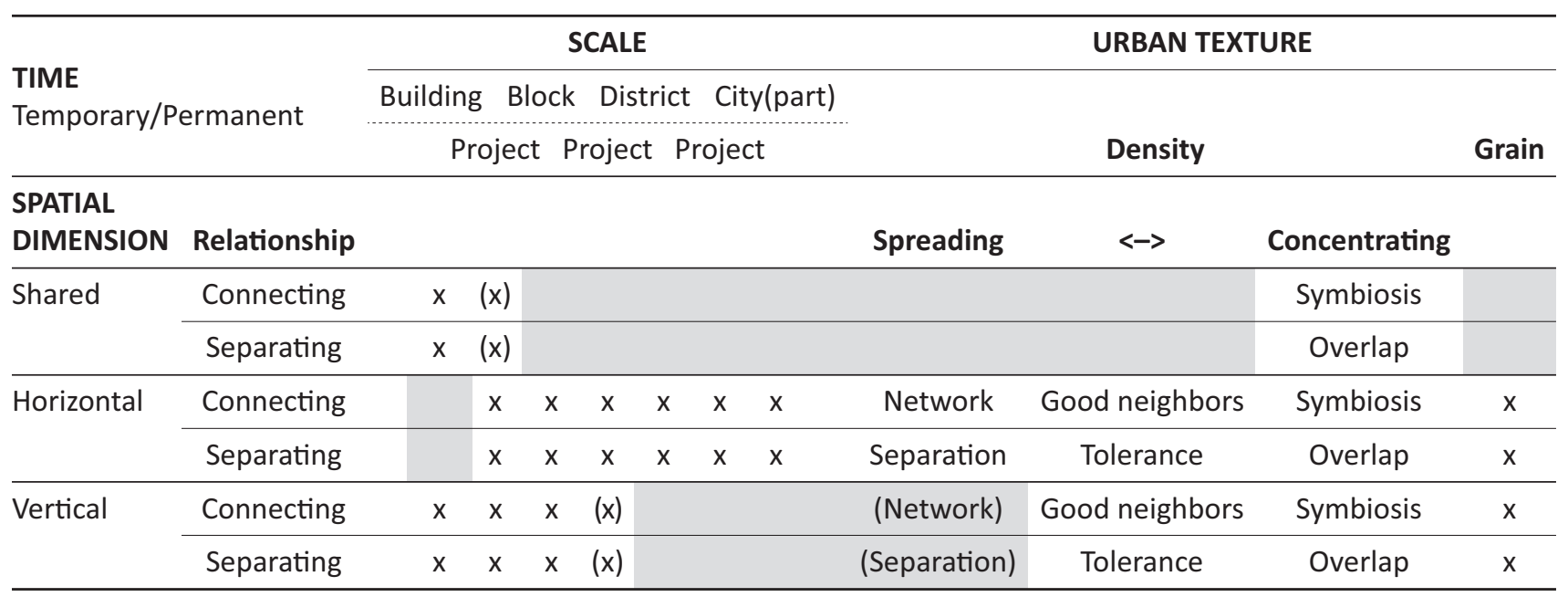




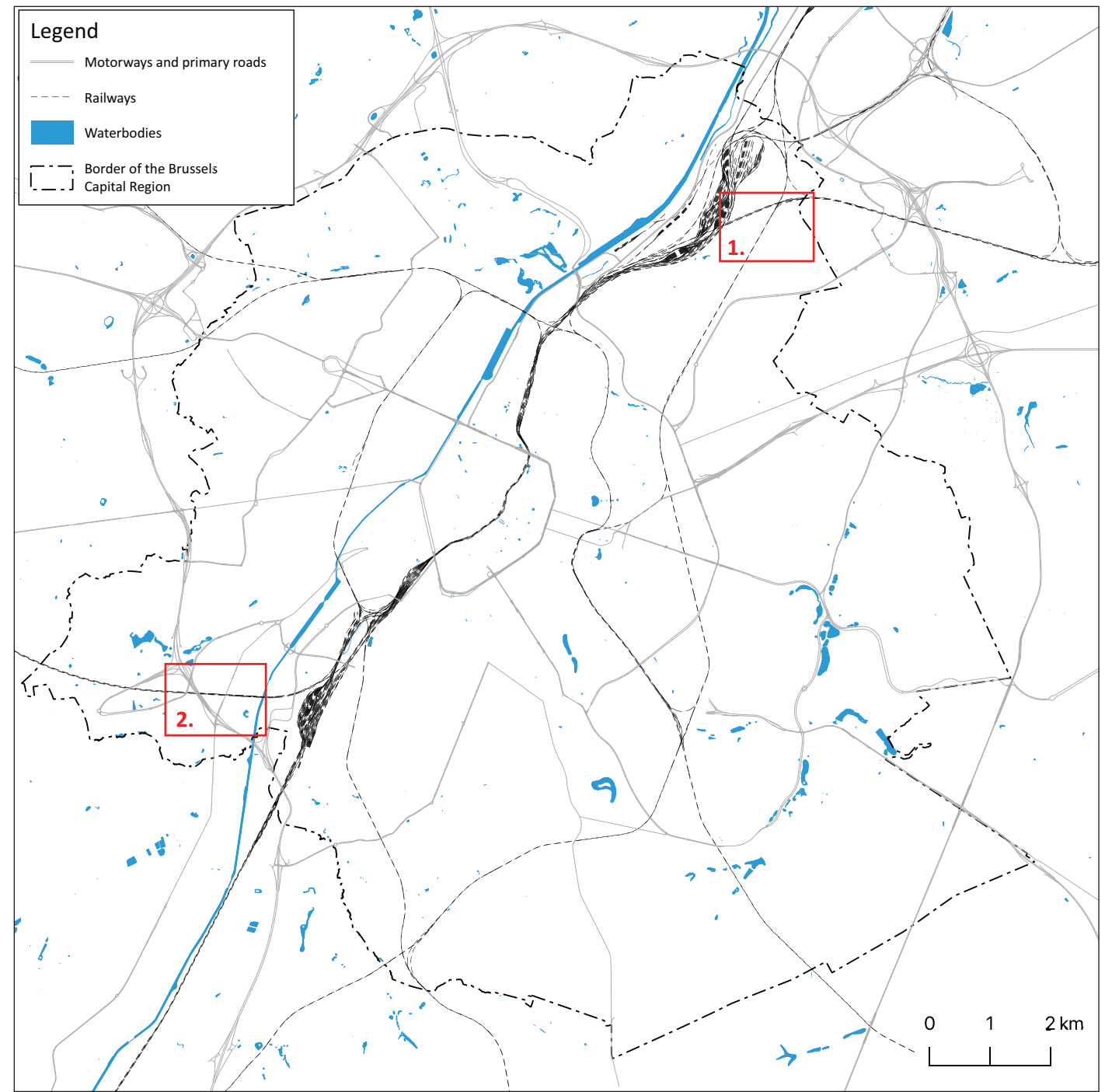

Figure 3. Map of the Brussels Capital Region. The NorthCity Haren project is located at no. 1 and the NovaCity and CityCampus projects are located at no. 2. The red rectangles correspond to the excerpts from the land-use map and aerial photographs in Figure 4. Mapped by Michael Ryckewaert. Sources: UrbIS (2020) and OpenStreetMap (2020).

have all obtained planning permission, and construction work has started in 2021. They are all situated at the edge of town, close to good public transport links, and on sites that allow or promote mixed-use. The similarity in the construction phase, timing, and urban location allow comparison on other topics, e.g., type of mixeduse, intensity of uses, visual and environmental relationships. We will analyse the qualitative and quantitative aspects of planned mixed-use developments using publicly available plans and 3D views. Accessibility, logistics arrangements, visual relationships, noise and smell reduction measures, and live-work combinations will be discussed together with the type of mixed-use.

Table 3 lists the basic characteristics of the three selected cases, all of which aim for a mixed-use on the project level and include housing and light industrial activities. As in the Urban Land Institute definition, the developments combine three or more revenueproducing uses (Rabianski et al., 2009; Witherspoon et al., 1976, as cited in Huston \& Mateo-Babiano, 2013, p. 4). NorthCity Haren combines private social housing with offices and light industrial units for sale by Futurn and to let by citydev.brussels. The latter two cater to different potential clients and have a different perspective on revenue creation, as citydev.brussels is governmentowned and Futurn is a private development company. NovaCity focuses on middle-class subsidised housing, light industrial units with and without showrooms, and retail in the second phase. In CityCampus, ateliers for food-related businesses are combined with student studios for a nearby school, single-family terraced housing, and social housing apartments (Table 3).

\section{Evaluation of Three Cases of Live-Work Mix Based on the Analytical Framework for Mixed-Use Projects}

In the analysis of the three cases, we will first situate them in the $\mathrm{H}-\mathrm{L}$ "dimensions versus scale" matrix 


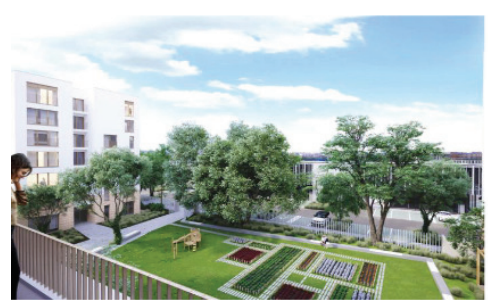

NorthCity Haren
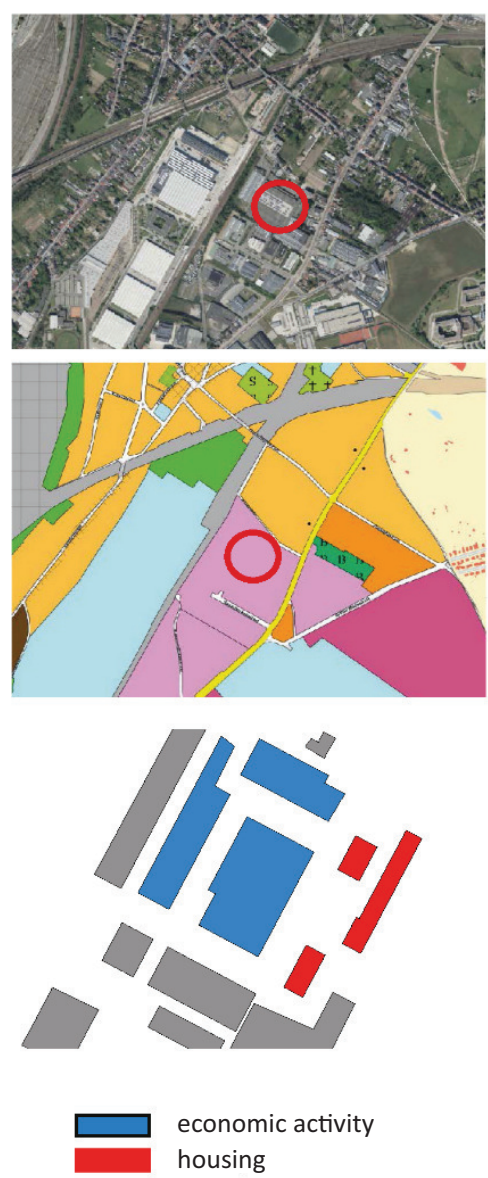

economic activity housing

areas of residence

mixed areas of residence strongly mixed areas of residence

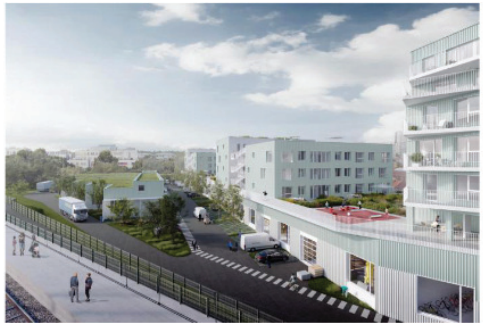

NovaCity
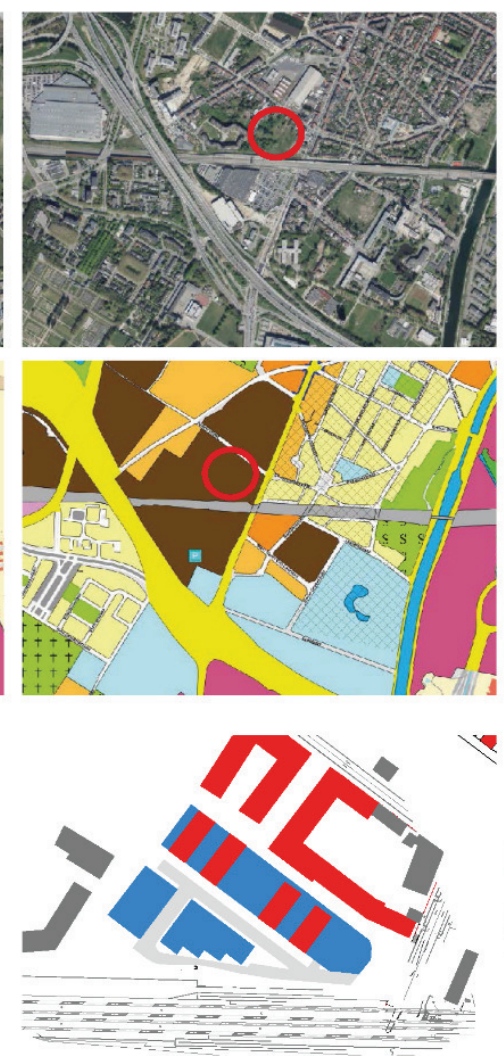

$\sqrt{10}$
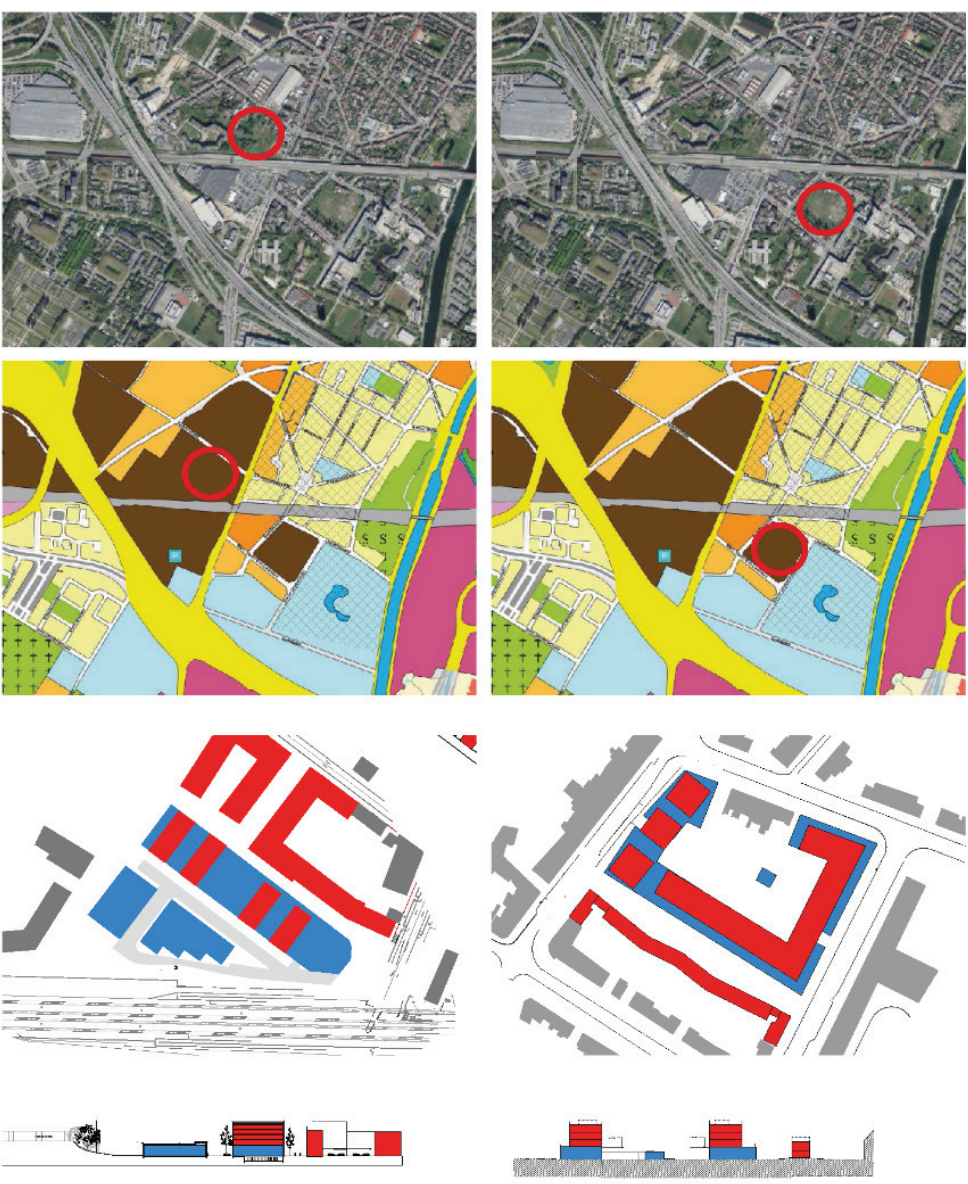

areas of urban production

enterprise areas in urban environment

areas for port activities and transportation areas

Figure 4. Renderings, spatial context, land use, and spatial lay out of three live-work mix projects in the Brussels Capital Region. Sources: Binst Architects and ORG permanent modernity (n.d.); BruGIS Team (n.d.); Pixelab (n.d.); Urban Nation Architects \& Associates (n.d.). Spatial lay out drawn by Jan Zaman based on citydev.brussels $(2018,2019)$ and Futurn (2019).

(Table 5). To analyse the functional aspects of the developments, we focus on a limited set of parameters that allow us to evaluate the potential for functional relationships and strategies to avoid (environmental) nuisances. We include five parameters from the standard environmental impact assessment topic areas of "landscape, visual qualities," "noise and vibrations," "air quality," and "transport" (Glasson et al., 2012): they are visual relationship, noise reduction strategies, smell avoidance strategies, access routes, and loading arrangements (Table 4). The visual relationship parameter, the nature of the access routes, and loading arrangements also allow assessing the nature of the functional relationships and the potential to establish connections between uses needed to situate the projects in the L-P scheme. The sixth and final parameter further assesses the possibilities for connections offered by other types of shared spaces in the projects. The "access," "loading," and "shared space" parameters also allow evaluating the permeability in the urban texture component.

As far as the functional relations of the L-P scheme are concerned, we will evaluate ex-ante the intended and potential functional relations between housing and productive activities based on the development aims and 
Table 3. Basic characteristics of three live-work mix projects in the Brussels Capital Region.

\begin{tabular}{|c|c|c|c|}
\hline Name & NorthCity Haren & NovaCity & CityCampus \\
\hline Land use zone & $\begin{array}{l}\text { Enterprise areas in an } \\
\text { urban environment }\end{array}$ & $\begin{array}{l}\text { Strongly mixed areas } \\
\text { of residence }\end{array}$ & $\begin{array}{l}\text { Strongly mixed areas } \\
\text { of residence }\end{array}$ \\
\hline District household density & $1,026 \mathrm{hh} / \mathrm{km}^{2}$ & $3,474 \mathrm{hh} / \mathrm{km}^{2}$ & $3,474 \mathrm{hh} / \mathrm{km}^{2}$ \\
\hline $\begin{array}{l}\text { District mix (\% of } \\
\text { non-residential use, 1997) }\end{array}$ & $\begin{array}{l}48.42 \% \\
\text { (adjacent district 97.16\%) }\end{array}$ & $34.89 \%$ & $34.89 \%$ \\
\hline $\begin{array}{l}\text { Project: } \mathrm{m}^{2} \text { (light) industrial } \\
\text { and material production }\end{array}$ & $12,554 \mathrm{~m}^{2}$ & $7,519 \mathrm{~m}^{2}$ & $5,370 \mathrm{~m}^{2}$ \\
\hline Project: $\mathrm{m}^{2}$ public services & $212 \mathrm{~m}^{2}$ & $0 \mathrm{~m}^{2}$ & $138 \mathrm{~m}^{2}$ \\
\hline $\begin{array}{l}\text { Project: } \mathrm{m}^{2} \text { offices, } \\
\text { immaterial production } \\
\text { and other }\end{array}$ & $1,033 \mathrm{~m}^{2}$ & $452 \mathrm{~m}^{2}$ & $0 \mathrm{~m}^{2}$ \\
\hline Project: $\mathrm{m}^{2}$ housing & $9,629 \mathrm{~m}^{2}$ & $7,482 \mathrm{~m}^{2}$ & $18,615 \mathrm{~m}^{2}$ \\
\hline Project: $\mathrm{m}^{2}$ green & $0 \mathrm{~m}^{2}$ & $2,454 \mathrm{~m}^{2}$ & $0 \mathrm{~m}^{2}$ \\
\hline $\begin{array}{l}\text { Number and average size } \\
\text { of economic units }\end{array}$ & $\begin{array}{l}\text { citydev.brussels: } 17-266 \mathrm{~m}^{2} \\
\text { Futurn: } 24-250 \mathrm{~m}^{2} \\
1,000 \mathrm{~m}^{2} \text { offices }\end{array}$ & $17-442 \mathrm{~m}^{2}$ & $18-298 \mathrm{~m}^{2}$ \\
\hline Ownership economic units & $\begin{array}{l}\text { citydev.brussels: rental } \\
\text { Futurn: sale }\end{array}$ & Rental & Rental \\
\hline Type of housing & $\begin{array}{l}\text { Privately owned social } \\
\text { housing: } 123 \text { apartments }\end{array}$ & $\begin{array}{l}63 \text { lower middle-income } \\
\text { apartments }\end{array}$ & $\begin{array}{l}\text { Social housing: } 70 \text { units } \\
\text { ( } 26 \text { terraced single-family } \\
\text { houses, } 44 \text { apartments) } \\
293 \text { student housing units }\end{array}$ \\
\hline Ownership housing & Rental & Sale & Rental \\
\hline
\end{tabular}

Sources: BISA.brussels (n.d.); citydev.brussels (2018, 2019); Futurn (2019); perspective.brussels (2018).

the spatial layout of the projects. We add the mixed-use type from the L-P scheme for each scale and each project in brackets to Table 5. Depending on how the projects will actually be used in practice once built, the nature of the relationship might change, indicated by arrows in Table 5. When the outcome is unsure or unlikely, we added a question mark. Both the $\mathrm{L}-\mathrm{P}$ and the $\mathrm{H}-\mathrm{L}$ scheme include a temporal dimension to determine if land uses in a particular place can alternate over time or not. Also here, we will assess the intended and potential for such alternation ex-ante, based on a reading of the planning documents of the projects. Finally, in the qualitative discussion of the cases, we will refer to urban texture characteristics such as "grain" and "density" where relevant. Within the four dimensions of mixed-use in the $\mathrm{H}$-L scheme, all developments share premises. As shown in Figure 3, NorthCity Haren has mainly mixed-use in a horizontal dimension, CityCampus a vertical dimension, and NovaCity is combining both horizontal and vertical dimensions.

\subsection{NorthCity Haren}

NorthCity Haren has no shared premises, horizontal or vertical mix at the building level. At the project level, there is no hard separation between housing and economic functions, creating a situation of "tolerance." At the project level, a horizontal connection is possible in the shared access road so this space is marked by an "overlap" of uses and could be the place where a "good neighbours" relation between housing and industrial use could develop. "Symbiosis" seems unlikely, as the design of this space is not intended to host joint activities between uses. At the building block level, the project introduces housing in a formerly single-use industrial block so there is "tolerance" at the building block level.

At the "district" level, the project is located along a road that separates a "typical housing area" from an "urban enterprise zone," in a part of town that is marked by a relatively low density and heavy infrastructures. Without aiming for a very intense model of mixed-use, the project introduces some density in a fragmented space marked by a mere "tolerance" and "separation" between low-density housing and industry, which occur in relatively coarse-grained patches. We could speak of "overlap" at the district level, but probably not of "symbiosis." As the scale of the project is rather limited, it cannot fundamentally alter the single-use character of this part of the city where, overall, the demarcations between industrial and residential areas remain quite 
Table 4. Spatial and functional relationships and mitigation of potential nuisances between land uses.

\begin{tabular}{|c|c|c|c|}
\hline & NorthCity Haren & NovaCity & CityCampus \\
\hline $\begin{array}{l}\text { Visual } \\
\text { relationship }\end{array}$ & $\begin{array}{l}\text { Views from housing and green } \\
\text { spaces to industrial sites } \\
\text { and offices. }\end{array}$ & $\begin{array}{l}\text { Secondary and side views from } \\
\text { the apartments on the } \\
\text { industrial street. }\end{array}$ & $\begin{array}{l}\text { View on public space and } \\
\text { limited view on yard due to } \\
\text { large canopy. }\end{array}$ \\
\hline $\begin{array}{l}\text { Noise } \\
\text { reduction } \\
\text { strategies }\end{array}$ & $\begin{array}{l}\text { Distance between housing and } \\
\text { industrial units. }\end{array}$ & $\begin{array}{l}\text { Special attention to floor } \\
\text { separating housing and industry. } \\
\text { Balcony increases distance and } \\
\text { reflects noise. }\end{array}$ & $\begin{array}{l}\text { Special attention to floor } \\
\text { separating housing and industry. } \\
\text { Large canopy increases distance } \\
\text { and reflects noise. Noisy } \\
\text { entrances for goods face } \\
\text { the yard. }\end{array}$ \\
\hline $\begin{array}{l}\text { Smell } \\
\text { avoidance } \\
\text { strategies }\end{array}$ & $\begin{array}{l}\text { Distance between housing and } \\
\text { industrial units. }\end{array}$ & $\begin{array}{l}\text { Special attention to floor } \\
\text { separating housing and } \\
\text { industry. }\end{array}$ & $\begin{array}{l}\text { Special attention to floor } \\
\text { separating housing and industry. } \\
\text { Large canopy increases distance } \\
\text { and might have an impact on } \\
\text { smell reduction. Direct vent } \\
\text { shafts from the industrial units } \\
\text { to the roof to evacuate odours } \\
\text { from the ground floor economic } \\
\text { activities. }\end{array}$ \\
\hline
\end{tabular}

Access routes Access routes between housing and industrial uses separate, but on the same public street. A connection is provided between the shared garden of the housing development and the shared yard. The access route does not create a shortcut between other public streets, so there is no increased permeability.

\section{Loading} arrangement

Loading and unloading from a shared yard and parking space, away from the housing development.

Shared spaces

A shared garden for the housing development and a shared yard for the economic units, but no space that combines both activities.
Access routes between housing and industrial uses separate and on different public streets.

As the new access route is open to the public, this increases permeability.

Loading and unloading from a shared yard and parking space, away from the housing development.

A shared garden for the housing development and a shared yard for the economic units, but no space that combines both activities.

\section{Access routes between} pedestrians and heavy goods vehicles are separate. Each economic unit has an entrance on the shared street. As this street is open to the public, this increases permeability.

Loading and unloading at the back of the ateliers, in a shared industrial yard. Bike parking and waste management facilities also located in the yard.

The streets surrounding the ateliers are shared between all uses, also open to the public. The inner yard is a shared space between economic activities. Shared student spaces (communal kitchen) face the entrances for heavy goods vehicles with a view of the industrial yard. The roof garden is shared between apartments and student housing. clear. It will not fundamentally change the coarse grain of the area.

To conclude, the project introduces affordable housing in a formerly industrial area. It serves as an inter- face between living and working in this part of the city. It is located near a new train station in the regional express train network. The project mainly stems from the ambitions of the Brussels Capital Region to increase 
Table 5. Mixed land use according to the $\mathrm{H}-\mathrm{L}$ scheme (Hoppenbrouwer \& Louw, 2005) by dimensions and scale.

\begin{tabular}{|c|c|c|c|c|c|}
\hline Level & Building & Project & Building-block & District & City \\
\hline \multirow[t]{3}{*}{$\begin{array}{l}\text { Shared premise } \\
\text { dimension }\end{array}$} & & $\begin{array}{l}\text { NorthCity Haren } \\
\text { (Overlap) }\end{array}$ & & & \\
\hline & & $\begin{array}{l}\text { NovaCity } \\
\text { (Separate } \rightarrow \\
\text { Overlap?) }\end{array}$ & & & \\
\hline & $\begin{array}{l}\text { CityCampus } \\
\text { (Overlap } \rightarrow \\
\text { symbiosis) }\end{array}$ & $\begin{array}{l}\text { CityCampus } \\
\text { (Overlap } \rightarrow \\
\text { symbiosis) }\end{array}$ & & & \\
\hline \multirow[t]{3}{*}{$\begin{array}{l}\text { Horizontal } \\
\text { dimension }\end{array}$} & & $\begin{array}{l}\text { NorthCity Haren } \\
\text { (Tolerance } \rightarrow \\
\text { Good } \\
\text { neighbours) }\end{array}$ & $\begin{array}{l}\text { NorthCity Haren } \\
\text { (Tolerance) }\end{array}$ & $\begin{array}{l}\text { NorthCity Haren } \\
\text { (Overlap) }\end{array}$ & $\begin{array}{l}\text { NorthCity Haren } \\
\text { (Tolerance) }\end{array}$ \\
\hline & & $\begin{array}{l}\text { NovaCity } \\
\text { (Overlap } \rightarrow \\
\text { Symbiosis?) }\end{array}$ & $\begin{array}{l}\text { NovaCity } \\
\text { (Overlap } \rightarrow \\
\text { Symbiosis?) }\end{array}$ & $\begin{array}{l}\text { NovaCity } \\
\text { (Overlap } \rightarrow \\
\text { Symbiosis?) }\end{array}$ & $\begin{array}{l}\text { NovaCity } \\
\text { (Overlap } \rightarrow \\
\text { Symbiosis?) }\end{array}$ \\
\hline & & $\begin{array}{l}\text { CityCampus } \\
\text { (Overlap } \rightarrow \\
\text { Symbiosis?) }\end{array}$ & $\begin{array}{l}\text { CityCampus } \\
\text { (Overlap) }\end{array}$ & $\begin{array}{l}\text { CityCampus } \\
\text { (Overlap } \rightarrow \\
\text { symbiosis?) }\end{array}$ & $\begin{array}{l}\text { CityCampus } \\
\text { (Overlap } \rightarrow \\
\text { symbiosis?) }\end{array}$ \\
\hline \multirow[t]{2}{*}{$\begin{array}{l}\text { Vertical } \\
\text { dimension }\end{array}$} & $\begin{array}{l}\text { NovaCity } \\
\text { (Tolerance } \rightarrow \\
\text { Good } \\
\text { neighbours?) }\end{array}$ & $\begin{array}{l}\text { NovaCity } \\
\text { (Tolerance } \rightarrow \\
\text { Good } \\
\text { neighbours?) }\end{array}$ & & & \\
\hline & $\begin{array}{l}\text { CityCampus } \\
\text { (Good } \\
\text { neighbours) }\end{array}$ & $\begin{array}{l}\text { CityCampus } \\
\text { (Good } \\
\text { neighbours) }\end{array}$ & & & \\
\hline Time dimension & & CityCampus & CityCampus & CityCampus & \\
\hline
\end{tabular}

the offer of affordable housing within its borders, while at the same time creating additional productive space. The location of the project is the result of an opportunity that presented itself, rather than a strategic intervention embedded in a larger vision. Nonetheless, within the constraints of the site, and the specificities of the location, the project succeeds in realising some of the goals of mixed-use development. It contributes to increased liveability, multiple-use, and transit-oriented development in this part of town.

\subsection{NovaCity}

The middle building of the NovaCity project has a vertical mix with housing on top of workshops. Special attention is devoted to the floor of this vertical mix building and protruding balconies create extra distance possibly reducing noise. Both uses are in a situation of "tolerance" and, if residents had a job in the workshops, a more intense relationship of "good neighbours" could develop. At the project level, the uses "overlap" horizontally in the vertical mix building. There is a focus on reducing hindrance of logistics, by organising separate shared spaces and access routes for industrial and residential uses. The only exception is the road between the verti- cal mix building and the residences, where the workshop might also entertain a relationship with this "residential" access road. This creates some potential for "overlap" in this shared space at the project level.

The project could be a host to a stronger relationship between housing and industry if a campaign would focus on attracting residents of the project, the building block, or the district, to have their business in the project, and as such move toward "symbiosis" at these levels. So far, there are no indications that such initiatives are supported actively. In addition, an integrated ownership structure for the housing and the businesses could improve this, whereas today they are governed by different ownership structures (housing for sale and business space for rent). Some further considerations at the district and city level are discussed after the evaluation of the CityCampus project as both projects are situated in the same district.

\subsection{CityCampus}

The CityCampus project has a vertical mix building with shared premises, combining business units for foodrelated activities with student housing for students attending classes in the nearby agri-food school campus 
CERIA/COOVI. At the building level, spatial elements are introduced to reduce nuisances, such as a large canopy, noise-reducing floors between the workshops, and student housing and vents. These devices and the "symbiosis" created by joint activities in the shared premises create a "good neighbours" relationship in the vertical sense within the building. At the project level, shared spaces are provided between similar land uses (housing and student housing) as well as between different land uses. The pedestrian interior street provides access to all uses, while the yard, serving mainly logistic purposes for the workshops, is visible from the student housing and kitchen and hosts (shared) bicycle parking. The project clearly wants to provide an "urban parterre" (Psenner \& Klodydek, 2017), where the street, ground floor, and courtyard work together as one entity.

Clearly, from a spatial point of view, there is at least (horizontal) "overlap" at the project, building block, and district level. From the organisational set-up, there is a clear aim to reach "symbiosis," at the project and district level. The ambition of the project is that students could have a job or do internships in the food-related spin-off companies in the project and live above. Later on, they might live in the neighbourhood and start a business in the workshops. The schools in the CERIA/COOVI agri-food campus could play a pivotal role in organising and sponsoring these exchanges and functional relationships at the project and district level. The intricate relationships between the student housing, the schools, the workshops, and the shared premises, also hint at alternating uses in time at the project and district level. If indeed these institutions take up the role of accommodating such relationships, true "symbiosis" at the project and district level could emerge.

\subsection{Advanced Mixed-Use in Response to High Development Pressures for Housing and Productive Space}

As indicated in Figures 3 and 4 and Table 3, the NovaCity and CityCampus projects are located in the same district on the southern edge of the Brussels Capital Region in the municipality of Anderlecht. This district hosts a garden city neighbourhood built in the first half of the 20th century in an area that was marked by small scale agriculture and vegetable farming, also explaining the origins of the agri-food school campus. The area is crossed by a series of infrastructures such as the Brussels-Ghent railway line, the Brussels-Charleroi canal, and the orbital motorway, resulting in spatial fragmentation. Two interrelated developments have marked the area. First of all, the area is developed by the Brussels Capital Region as a mobility hub since the 2010s, with the opening of a new metro-stop, the opening of a new train station, and commuter parking on the motorway exit. Second, in the wake of these infrastructural improvements, vacant land is developed for housing and mixed-use projects such as NovaCity and CityCampus.
These developments will alter the composition of the housing stock that is dominated today by single-family homes, as well as the household composition with a share of families with children that is higher than the regional average. When all anticipated projects are realised, the number of inhabitants in the district will increase by one-fifth to a quarter.

In short, as a result of the regional policies, the low density, semi-agricultural, and fragmented edge city district will transform into a very accessible peripheral development node. The NovaCity and CityCampus projects developed by the regional public developer citydev.brussels fit in this policy. The policy and ambition are to provide both productive spaces and affordable housing on the limited land available. This leads to strongly concentrated and very dense mixed-use projects that apply more complex mixed-use configurations (vertical mix, overlap, and symbiosis). Fitting within this regional policy, the projects can alter the overall density and degree of mixed-use of this part of the city. Mixed-use at block and district level of the "good neighbours" or "tolerance" kind is clearly present in the area today. The introduction of additional highdensity multi-family housing in an area marked by a relatively high share of single-family housing creates tensions. Residents feel that the area mainly needs green spaces, additional single-family housing, and renovations of existing housing. At the level of this part of the city, it remains to be seen whether the mixed-use projects will result in an increased "overlap" and tensions between productive and residential uses of different kinds, or rather in fruitful "symbiosis," increasing the liveliness and liveability of this part of the Brussels Capital Region.

\section{Discussion and Conclusion}

The integrated application of two conceptual schemes of mixed-use to three live-work mix projects in Brussels shows the need for a multi-level conceptual framework of mixed-use. Whereas the $\mathrm{H}-\mathrm{L}$ scheme focuses on spatial arrangements and the urban texture of mixity and considers different levels of scale, the L-P scheme considers spatial arrangements and functional relationships between different land uses. In that sense, both schemes complement each other and compensate for their mutual deficiencies. Indeed, in the L-P scheme, some of the models of mixity, such as "tolerance," "separate," or "network" apply to single land-use configurations where there is no question of mixed-use, depending on the spatial scale. If "scale" is taken into consideration, it becomes clear that at the project or building block level, these configurations do refer to mixed-use. Conversely, while the $\mathrm{H}-\mathrm{L}$ scheme distinguishes between shared premises, horizontal or vertical mixity, it does not consider functional relationships between different land uses. Moreover, the L-P scheme further details the density dimension of the urban 
texture component, distinguishing between spreading and concentrating land uses. The time dimension discerns between the permanent and temporary nature of mixity, which we assessed based on expected practices of use in the projects under construction. For an ex-post evaluation of mixed-use projects, design and planning strategies, spatial configurations at various levels of scale, urban texture characteristics such as density and grain, functional relationships, as well as the temporal dimension, should be considered.

It appears that the design and conception of mixeduse projects are highly contextual. Vertical mix and a close functional relationship between activities are often presented as a guiding image to break away from functionalist zoning and its adverse effects (Lane \& Rappaport, 2020; Rappaport, 2017). As such, there is a risk that reaching "symbiosis" between activities in mixed projects is considered as the holy grail of mixed-use. Aiming for symbiosis could result in mere overlap without the added value of increased liveability, and even in increasing conflicts and tensions between uses, as illustrated in the CityCampus and NovaCity projects at the district and city level. This further illustrates that the analytical framework combining components and types of mixed-use from the $\mathrm{H}-\mathrm{L}$ and L-P scheme should not be considered as a normative framework.

Indeed, the findings of this analysis of three mixeduse projects suggest that less intense forms of mixity such as "good neighbours," "overlap," and "tolerance" also correspond to valid spatial planning goals in cities that try to combine productive city policies to develop affordable housing within a limited territory, a context of soaring land prices and traffic congestion. The aims to increase density and keep essential economic activities within the city, close to the "consumers" of such essential services and goods, as well as to a labour force in search of short-term skilled jobs, seem to justify the choice for projects that combine activities to various degrees without, however, reaching "symbiosis."

It seems that symbiotic mixity is only to be achieved when specific conditions are met. Notably, the combined programs or activities should have functional and organisational links and some form of governance should be in place to organise shared use in space and time. A government agency such as citydev.brussels could take up this role, but also the introduction of leasehold schemes, where joint ownership of land for mixed projects leads to joint management, could result in better governance of relationships between different land uses (De Boeck \& Ryckewaert, 2020). This could also be part of the extended role of the curator, a unit or agency responsible for the integration, management, and networking of productive uses in the city as proposed in productive city strategies (Cities of Making, 2020).

As such, the productive city discourse introduces a new motivation to pursue mixed-use development, beyond the "traditional" goals of combatting the nega- tive aspects of single-use development, such as increasing the liveability and liveliness of urban environments. As our examples show, projects should find a balance between the need to intensify land use to accommodate conflicting and competing land uses (residences and production notably) and these established aims of mixed-use development.

Finally, the various types of mix-good neighbours, tolerance, overlap, symbiosis-come with their own design and spatial strategies. In the case of tolerance and good neighbourship, the careful design of the separation between uses at the building level, project and building block level, as well as in terms of logistic and access flows seem the most essential. In the case of the symbiotic mix, the design effort should focus on clever solutions for shared spaces, situated between different uses. Symbiosis will mainly emerge if these spaces allow for multiple uses (possibly alternating in time) and/or for joint activities between different land uses that strengthen the links between residential and productive uses. Examples could be a shared garden that serves as a space for lunch breaks for workers, professional workshops where inhabitants can do DIY work or lend tools for jobs in and around the house, among many others.

\section{Acknowledgments}

We would like to thank the three anonymous reviewers and the scientific editors for their comments. The research for this article was funded by the interdisciplinary research project "Building Brussels. Brussels' city builders and the production of space, 1794-2015" of the Vrije Universiteit Brussel and the on-going research program "Spatial-Economic Networks" of the Flemish Planning Bureau for the Environment and Spatial Development. This article relies in part on the research conducted by Sarah De Boeck at Vrije Universiteit Brussel until December 2020. Since January 2021, Sarah De Boeck has been the director of the Territorial Knowledge Department at perspective.brussels, the urban planning agency of the Brussels Capital Region. The views expressed in this article are exclusively based on academic research conducted before 2021 and do not translate the views or policies of any government agency of the Brussels Capital Region.

\section{Conflict of Interests}

The authors declare no conflict of interests.

\section{References}

Binst Architects, \& ORG permanent modernity. (n.d.). CityCampus. citydev.brussels. http://www.citydev. brussels/fr/projets/citycampus

BISA.brussels. (n.d.). Wijkmonitoring [Neighborhood monitoring]. https://wijkmonitoring.brussels 
Borret, K., Lacasse, G., \& Collet, J. (2018). Brussels productive city. Bouwmeester Maitre Architecte.

BruGIS Team. (n.d.). brugiswebapp. https://gis.urban. brussels/brugis/\#

Castells, M., \& Hall, P. (1994). Boston's highway 128. High-technology reindustrialization. In M. Castells \& P. Hall (Eds.), Technopoles of the world. The making of twenty-first-century industrial complexes (pp. 29-39). Routledge.

Choay, F. (1965). L'urbanisme, utopies et réalités. Une anthologie [Urbanism, utopias and realities. An anthology]. Seuill.

Cities of Making. (2018). Cities report. https://citiesof making.com/wp-content/uploads/2018/05/CoM_ CityReport-0523-LR.pdf

Cities of Making. (2020). Foundries of the future. A guide to 21st century cities of making. TU Delft Open.

citydev.brussels. (2018). Planning permission application 01/PFD/1697838 (CityCampus project). https:// openpermits.brussels/fr/_01/PFD/1697838

citydev.brussels. (2019). Planning permission application 01/PFD/1701869 (NovaCity project). https:// openpermits.brussels/fr/_01/PFD/1701869

Curran, W. (2007). "From the frying pan to the oven": Gentrification and the experience of industrial displacement in Williamsburg, Brooklyn. Urban Studies, 44(8), 1427-1440. https://doi.org/10.1080/ 00420980701373438

De Beule, M., Périlleux, B., Silvestre, M., \& Wauty, E. (2017). Brussel geplande geschiedenis. Stedenbouw in de $19 e$ en 20e eeuw [Brussels planned history. Urban design in the 19th and 20th centuries]. Meert.

De Boeck, S., Degraeve, M., \& Vandyck, F. (2020). Maintaining small-scale production space in the city: The case of Brussels construction companies (1965-2016). Brussels Studies, 2020(General collection no. 147). https://doi.org/10.4000/brussels.5023

De Boeck, S., \& Ryckewaert, M. (2020). The preservation of productive activities in Brussels: The interplay between zoning and industrial gentrification. Urban Planning, 5(3), 351-363. https://doi.org/10.17645/ up.v5i3.3092

De Maesschalck, F., De Rijck, T., \& Heylen, V. (2015). Crossing borders: Social-spatial relations between Brussels and Flemish Brabant. Brussels Studies, 2015(General collection no. 84). https://doi.org/ $10.4000 /$ brussels. 1260

Dessouroux, C., Bensliman, R., Bernard, N., De Laet, S., Demonty, F., Marissal, P., \& Surkyn, J. (2016). Housing in Brussels: Diagnosis and challenges. Brussels Studies, 2016(Synopsis no. 99). https://doi.org/ 10.4000/brussels.1353

Ferm, J., \& Jones, E. (2016). Mixed-use 'regeneration' of employment land in the post-industrial city: Challenges and realities in London. European Planning Studies, 24(10), 1913-1936. https://doi.org/ 10.1080/09654313.2016.1209465

Ferm, J., \& Jones, E. (2017). Beyond the post-industrial city: Valuing and planning for industry in London. Urban Studies, 54(14), 3380-3398. https://doi.org/ 10.1177/0042098016668778

Fischler, R. (1998). The metropolitan dimension of early zoning: Revisiting the 1916 New York City ordinance. Journal of the American Planning Association, 64(2), 170-188. https://doi.org/10.1080/ 01944369808975974

Futurn. (2019). Planning permission application 04/PFD/671586 (NorthCity Haren project). openpermits.brussels. https://openpermits.brussels/fr/_04/ PFD/671586

Gehl, J. (2011). Life between buildings: Using public space. Island Press.

Glasson, J., Therivel, R., \& Chadwick, A. (2012). Introduction to environmental impact assessment (4th ed.). Routledge.

Gold, J. R. (1998). Creating the charter of Athens: CIAM and the functional city, 1933-43. The Town Planning Review, 69(3), 225-247.

Government of the Brussels Capital Region. (2001). Plan regional d'affectation du sol [Regional land use plan].

Grant, J. (2002). Mixed use in theory and practice: Canadian experience with implementing a planning principle. Journal of the American Planning Association, 68(1), 71-84. https://doi.org/10.1080/ 01944360208977192

Hebbert, M. (2003). New urbanism-The movement in context. Built Environment, 29(3), 193-209. https:// doi.org/10.2148/benv.29.3.193.54285

Hirt, S. (2007). The devil is in the definitions. Journal of the American Planning Association, 73(4), 436-450. https://doi.org/10.1080/01944360708978524

Hoppenbrouwer, E., \& Louw, E. (2005). Mixed-use development: Theory and practice in Amsterdam's eastern docklands. European Planning Studies, 13(7), 967-983. https://doi.org/10.1080/ 09654310500242048

Huston, S., \& Mateo-Babiano, I. (2013). Vertical mixeduse communities: A solution to urban sustainability? Review, audit and developer perspectives July 2013 [Conference paper]. 20th Annual European Real Estate Society Conference, Vienna, Austria.

IABR-Atelier Brussels Productive Metropolis. (2016). A good city has industry. BOZAR-Paleis voor Schone Kunsten.

Jacobs, J. (1993). The death and life of great American cities. Vintage.

Lane, R. N., \& Rappaport, N. (2020). The design of urban manufacturing. Routledge.

Leinfelder, H., \& Pisman, A. (2008). A methodological framework for a political approach of mixed land use, tested in the urbanised region of Flanders, Belgium [Conference paper]. 4th Joint ACSP-AESOP Conference "Bridging the Divide: Celebrating the City," Chicago, IL, USA.

Logan, T. H. (1976). The Americanization of German zoning. Journal of the American Institute of 
Planners, 42(4), 377-385. https://doi.org/10.1080/ 01944367608977742

London City Hall. (2021). The London plan: The spatial development strategy for Greater London. Greater London Authority. https://www.london.gov.uk/ sites/default/files/the_london_plan_2021.pdf

Mumford, E. (2000). The CIAM discourse on urbanism, 1928-1960. MIT Press.

National Academies of Sciences, Engineering, and Medicine. (2004). Transit-oriented development in the United States: Experiences, challenges, and prospects. The National Academies Press.

OpenStreetMap. (2020). Belgium [Data set]. Geofabrik. https://download.geofabrik.de/europe/belgium. html

Orban, A., Trenado, C. S., \& Vanin, F. (2021). Who benefits from productive activities? Analysis of the case of Cureghem. Brussels Studies, 2021(General collection no. 153). https://doi.org/10.4000/brussels.5358

perspective.brussels. (2018). Plan régional d'affectation $d u$ sol. Dispositions relatives à l'affectation du sol: Version coordonnée [Regional land use plan. Planning prescriptions linked to the coordinated version of land use] https://perspective.brussels/sites/default/ files/documents/pras_180104_prescriptions_ coordonnees_officieuses.pdf

Pixelab. (n.d.). NovaCity. citydev.brussels. http://www. citydev.brussels/fr/projets-logement/novacity-i

Psenner, A., \& Klodydek, K. (2017). Researching the morphology of the city's internal micro structure: UPM urban parterre modelling. In 24th ISUF International Conference: Book of Papers (pp. 1245-1254). Universitat Politècnica de València.

Rabianski, J., Gibler, K., Tidwell, O. A., \& III, J. S. C. (2009). Mixed-use development: A call for research. Journal of Real Estate Literature, 17(2), 27.

Rappaport, N. (2017). Hybrid factory | Hybrid city. Built Environment, 43(1), 72-86. https://doi.org/10.2148/ benv.63.3.72

Rappaport, N. (2020). Vertical urban factory. Actar.

Rosenberger, M. (Ed.). (2017). Fachkonzept Produktieve Stadt [Spatial concept productive city]. Stadtentwickelung Wien.

Rowley, A. (1996). Mixed-use development: Ambiguous concept, simplistic analysis and wishful thinking? Planning Practice \& Research, 11(1), 85-98. https:// doi.org/10.1080/02697459650036477

Ryckewaert, M. (2011). Building the economic backbone of the Welfare State in Belgium. Infrastructure, planning and architecture 1945-1973. 010.

Urban Nation Architects \& Associates. (n.d.). NorthCity. citydev.brussels. http://www.citydev.brussels/ $\mathrm{fr} /$ projets/northcity

UrbIS. (2020). UrbIS-ADM [Data set]. Datastore.brussels. https://datastore.brussels/web/urbis-download

Uyttebrouck, C., Remøy, H., \& Teller, J. (2021). The governance of live-work mix: Actors and instruments in Amsterdam and Brussels development projects. Cities, 113, Article 103161. https://doi.org/10.1016/ j.cities.2021.103161

van Eesteren, C., \& van Rossem, V. (1997). Het idee van de functionele stad. Een lezing met lichtbeelden van 1928 [The idea of the functional city. A lecture with slides from 1928]. Nai.

van Es, E., Harbusch, G., Maurer, B., Pérez, M., Sommer, K., \& Weiss, D. (Eds.). (2014). Atlas of the functional city: CIAM 4 and comparative urban analysis. Thoth.

van Gameren, D., Kuitenbrouwer, P., \& Schreurs, E. (2019). Home work city: Living and working in the urban block. DASH-Delft Architectural Studies on Housing.

Vandyck, F. M., Bertels, I., Wouters, I., \& Ryckewaert, M. (2020). Urban industries and the production of space: A typomorphological analysis of the mixed urban fabric around the historical national road Jetsesteenweg in Brussels, Belgium. Urban Morphology, 24(2), 200-215.

Werksviertel. (n.d.). Werksviertel München. https:// werksviertel.de/?page_id=410\&lang=en

Witherspoon, R., Abbett, J. P., Gladstone, R. M., \& Institute, U. L. (1976). Mixed-use developments: New ways of land use. Urban Land Institute.

Yoon, H., \& Currid-Halkett, E. (2015). Industrial gentrification in West Chelsea, New York: Who survived and who did not? Empirical evidence from discretetime survival analysis. Urban Studies, 52(1), 20-49. https://doi.org/10.1177/0042098014536785

\section{About the Authors}

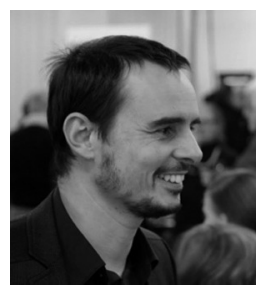

Michael Ryckewaert is associate professor of urbanism and program director of the MSc in urbanism and spatial planning at the Vrije Universiteit Brussel. He is also associate director of the Cosmopolis Centre for Urban Research. His research focuses on housing, spatial policy, urbanism history and theory, and the role of economic activities in urbanisation in Belgium. 


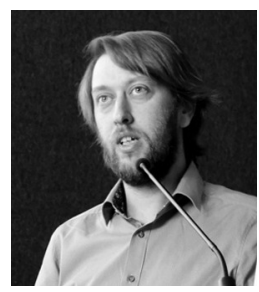

Jan Zaman was trained as an urbanist and spatial planner and works for the Flemish government administration. He specialises in economic aspects of spatial planning, and cross-border cooperation between Flanders and the Brussels capital region. Within the research program "Spatial-economic networks," he works in a team that strives to have the right company in the right place: in mixed environments where possible, in business parks where necessary, so that no net land take is needed to provide space for economic activities.

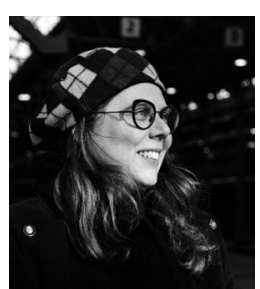

Sarah De Boeck is a doctor in interdisciplinary studies at the Vrije Universiteit Brussel and director of the Territorial Knowledge Department at perspective.brussels. Her research focuses on how to shape the coexistence between economic activity and liveability in metropolitan areas. 